\title{
MAORI FISHERIES 1986-1998: A REFLECTION
}

\author{
$R$ P Boast
}

In this article Richard Boast considers the statutory settlements of Maori fishing claims made in 1989 and 1992. These settlements are seen as examples of a distinctive method of dealing with Maori grievances routinely used in the New Zealand legal and political system. He also considers the aftermath of the legislation, and the extent to which the recent claims of Urban Maori authorities have questioned the entire settlement process as it has evolved to date.

\section{INTRODUCTION}

This article is focused not so much the minutiae of the current situation regarding the "Maori fisheries" issue, nor the by now very hackneyed topic of the legal basis of Maori claims to marine fisheries, but rather on the actual legal nature of the settlement process as it has evolved up to the present time. ${ }^{1}$ Events since 1986 form a fairly astonishing saga, demonstrating if nothing else the propensity of the New Zealand politico-legal system to create elaborate edifices of statute based on the fairly slender foundations of political deals. If there is an Ariadne's thread through the labyrinth, it is the importance of the political and pragmatic as opposed to the legal and constitutional. In fact, the main legal and constitutional

\footnotetext{
Senior Lecturer in Law, Victoria University of Wellington. An earlier version of this article was read as a paper to the Energy and Natural Resources Law Association on 25 November 1997. The law is stated as at 31 October 1998

1 There is a substantial literature on the subject now in print. most of which tends to adopt a critical stance towards the 1989 and (especially) the 1992 settlements. A useful overview written by nonlawyers is P Ali Memon and R C Cullen "Indigenous Fisheries in New Zealand" in Richard Howitt and others (eds) Resources, Nations and Indigenous Peoples (Oxford University Press, Melbourne, 1996) 252264. A great deal of the commentary by legal scholars suffers from a lack of appreciation of the costs and uncertainties involved in continuing with the substantive civil proceedings.
} 
questions surrounding the whole notion of "Maori fisheries" have never been resolved, and, what is more, elaborate precautions have now been taken to ensure that they never will be.

By 1988 the Labour governmenthad made the key concession that it was meaningful to speak of Maori property rights in sea fisheries and that the only issue was to decide on what percentage of the resource could be said to be "Maori"-owned. ${ }^{2}$ But this is a proposition that needs to examined with some care. Is it meaningful to speak of "Maori" property rights in fisheries? In one sense perhaps it is, in that supposing that British colonisation had never taken place and the Treaty of Waitangi had never been signed, there would have been a corpus of rights in fisheries attached to "Aotearoa" which its (presumably) "Maori" population would have continued to own, in the sense that the Thai people, say, own the fisheries resources of Thailand. In fact in terms of the indigenous customary law, fishing rights were not general to "Maori" but were highly localised. ${ }^{3}$ Some Maori leaders have taken pains to distance themselves from any claim to resources based on a criterion of Maori ethnicity on the basis that to do so is fundamentally "racist" - the settlements are not with "Maori" as an ethnic section of the New Zealand community but rather with political entities,

2 This concession was made at least by the time the Joint Working Party set up in late 1987 filed its two reports in early July 1988. The Maori and Crown representatives on the Joint Working Party proved unable to agree on a common formula. Crown representatives advocated that all quota be held by a corporation which would be $25 \%$ Maori-owned and $75 \%$ Crown-owned (the Maori share reflecting the value of the inshore fishery); but the Maori representatives filed a separate report which argued that the entire resource was Maori-owned, but that Maori were willing to vest $50 \%$ of the resource in the Crown: see "Fisheries factions still divided" The Dominion, Wellington 2 July 1988.

3 See especially Alan Ward, "'Overview' submission of Professor Alan Ward in the Ngai Tahu fishing rights claim before the Waitangi Tribunal", unpublished paper presented to the Waitangi Tribunal, 1992 (copy in possession of the author). Ward tends to reject notions that land and sea property rights were a physical and spiritual unity; rather he strongly stresses the local and specific nature of Maori customary property rights in fisheries and argues, too, that significant terminological problems have been caused "from the attempt to use English terminology on subtly different Polynesian concepts and practices" Ward, Overview, 2 The complexity of Maori fishing rights has long been recognised: James Mackay told an 1869 parliamentary committee on the Shortland (Thames) Foreshore Bill in 1869 that fisheries "are not considered as the common property of all Natives in the Colony; but certain hapus or tribes have the right to fish over one mud flat and other Natives over another": see "Report of the Select Committee on the Thames Sea Beach Bill" [1869] AJHR E-7, 7. A considerable amount of Maori testimony regarding fisheries management practices is preserved in the Minute Books of the Maori Land Court. One example is the evidence relating to Ninety-Mile Beach in (1957) Northern MB 7-67. This evidence certainly gives a detailed picture of fisheries management by particular kin-groups who claimed descent from a particular founding ancestor by the use of rahui (prohibitions) and other methods. 
iwi or tribes, membership of which is determined by descent. ${ }^{4}$ All this may sound like a recondite issue of interest only to anthropologists, but in fact the precise nature of Maori property rights in fisheries has become critically important at the present time.

\section{PROPERTY RIGHTS AND NATURAL RESOURCES LAW}

The Maori fisheries issue has of course been around for a long time, indeed since 1840, but for present purposes we can regard everything before 1986 as prehistory, of interest mainly to legal archaeologists. ${ }^{5}$ The transforming event was the Fisheries Amendment Act 1986, which

4 The point is forcefully put by Sir Tipene O'Regan in "A Ngai Tahu Perspective on Some Treaty Questions" in Geoff McLay (ed) Treaty Settlements: the Unfinished Business (NZ Institute of Advanced Legal Studies and Victoria University of Wellington Law Review, 1995) 88, 98-9: "It is as a Ngai Tahu that I hold interests in the Treaty rights of my people. I do not hold them as a Maori any more than I hold them as a 'New Zealander'." In the United States, as a comparative example, Federal Courts and the United States Supreme Court have held that giving effect to Indian treaty rights is not a breach of the equal protection clause of the Fourteenth Amendment: non-Indians are not being discriminated against, but rather treaties are being given effect to: see United States $v$ State of Washington (1974) $384 \mathrm{~F}$ Supp 312, 332; United States v State of Michigan (1979) 471 F Supp 192, 266 (WD Mich, 1979); State of Washington $v$ Washington State Commercial Passenger Fishing Vessel Association (1979) 443 us 658.

5 For a full listing of the relevant statutory provisions before 1986 see the Waitangi Tribunal's Muriwhenua Fishing Report, Wai 22 (Department of Justice, Wellington, 1988) Appendix 7. Section 14 of the Sea-fisheries Amendment Act 1903 stated that "nothing in this Act shall affect any Maori fishing rights". This was itself pre-figured by earlier statutory attempts to recognise Maori fishing rights protected by the Treaty of Waitangi: See Fish Protection Act 1877 s 8; Oyster Fisheries Act 1892 s 14; Sea-Fisheries Act 1894 ss 17, 72; Sea-Fisheries Amendment Act 1896 s 3; Maori Councils Act 1900 s 6; Maori Councils Amendment Act 1903 s 4(1). Section 77(2) of the Fisheries Act 1908 was to the same effect as s 14 of the Sea-Fisheries Amendment Act 1903. However s 77(2) was read restrictively by the Supreme Court in Waipapakura v Hempton (1914) 33 NZLR 1069, essentially to mean that the rights so protected could only be statutory. Stout CJ's reasoning was that the only source of Maori fishing rights was the Treaty of Waitangi: this, however, had never been incorporated by statute and therefore "the Court of Appeal is helpless to give effect to its provisions." As the Fisheries Act, in this view, did not itself create fishing rights for the Maori people the Court had no option but to operate on the basis of the Common Law, which is that in tidal waters all have a right to fish and that special rights to take fish must be sourced in statute. (The obvious flaw - obvious, that is, to us but clearly not to the New Zealand Court courts in 1908 - in Stout CJ's reasoning is that no account is taken of Maori fishing rights deriving not from the Treaty but separately from the doctrine of aboriginal title.) Section 88(2) of the Fisheries Act 1983 stated that "Nothing in this Act shall affect any Maori fishing rights" (the word "existing" being deleted from the older wording of the 1908 Act). However in Te Weehi $v$ Regional Fisheries Officer [1986] 1 NZLR 680 Williamson J reconsidered Waipapakura in the light of the doctrine of aboriginal title and held that the appellant was exercising a customary Maori fishing right sourced in the Common Law and protected by the legislation: this was a customary non-territorial property right which had never been extinguished (Te Weehi, 692). The full implications of Te Weehi were not fully 
substantially amended the Fisheries Act 1983 to bring into operation the Quota Management ("QMS") system. The 1986 Act was a reaction against the former regime of open slather and government subsidy, which had led to a massive expansion of the fishing industry from 1963. ${ }^{6}$ At the same time the inshore fishery dramatically declined, perhaps as a result of overfishing.

The 1986 amendment was conceptually innovative, and attempted to escape from the older regulated system which contained no incentives for fishers to conserve the resource. The solution was to privatise the resource by creating valuable, transferable property rights in it which could operate in a free market. The legislation is based around the concept of quota, a fraction of a particular "total allowable commercial catch" for a particular fish stock defined by reference to species and particular quota management areas, these latter being divisions of the New Zealand territorial sea and the Exclusive Economic Zone. Apart from rock lobster, quota is allocated in perpetuity, and holders acquire a harvesting right, measured as a specific tonnage for a specific quota management area for a fixed time (1 year). Quota can be thought of as slices of a variable pie - the shape and relative size of one's slice stays the same, depending on the quota one has accumulated, but the pie itself expands or contracts from year to year depending on the size of the total annual commercial catch, fixed by the Ministry each October. ${ }^{7}$ Quota give rise to an "annual catch entitlement" in accordance with elaborate formulae set out in sections 65 and 66 of the Fisheries Act 1996.

It is no misnomer to regard QMS as resource management by property rights. Individual transferable quota is clothed with the attributes of property by section 27 of the current Act. The statutorily-defined "characteristics" of individual transferable quota are that it is "to be allocated in perpetuity", that it "perpetually generates a right to receive an annual catch

worked out when the Fisheries Amendment Act 1986 was enacted.

6 For an authoritative discussion of the main shifts in New Zealand fisheries management policy in the twentieth century see Rowan Taylor and others, The State of New Zealand's Environment (Ministry for the Environment/GP Publications, Wellington, 1997) 9, 85-107.

7 Fisheries Act 1996 ss 20 and 21. In Fixing the Total Allowable Commercial Catch (TACC) the Minister is required to make allowance, inter alia, for Maori customary non-commercial fishing interests (s 21 (1)(a)(i)). The TACC is itself a subset of the total allowable catch fixed under s 13: essentially the total allowable catch is required to maintain the stock "at or above the level that can produce the maximum sustainable yield". The fixing of the TACC is certainly subject to judicial review: see New Zealand Fishing Industry Association v Minister of Fisheries (22 July1997) unreported, Court of Appeal, CA 82/97, 83/97, 96/97. 
entitlement for that stock", and that it may be traded, secured, and caveated in any manner permitted by the Act. Compared to the very limited rights of tradeability permitted, say, for water permits under the Resource Management Act 1991 - the Resource Management Act is a consents-based, rather than a property-based, system of resource management ${ }^{8}$ - fisheries quota are fairly freely tradeable. ${ }^{9}$ The legislation goes out of its way not only to ensure that quota undoubtedly are "property", but to equate such property rights with registrable interests in real property. The Act very elaborately provides for a system of registers, the provisions being simply lifted from the Land Transfer Act $1952 .{ }^{10}$ The legislation amounts to a remarkable effort by the state to actually create property rights where none existed before. At common law there are no property rights in ocean fish - fish, like foxes or birds are ferae naturae and are unowned until caught: in fact it is, to the common law mind, the act of catching a fish or whale which creates the property right ${ }^{11}$ - so that the new fisheries management regime implemented in 1986 certainly cannot be regarded as a reversion to the common law.

There is no guarantee that managing a natural resource through a system of tradeable property rights will necessarily solve all management problems. The Ministry for the

8 By s 123 of the Resource Management Act 1991 (RMA) water permits granted by regional councils may be granted for a maximum period of 35 years. The circumstances under which consents are tradeable are very restricted (RMA, s 136); and moreover s 122 (1) explicitly states that resource consents are "neither real nor personal property".

9 The main restrictions are set out in s 56, which restricts the transfer of quota to "overseas persons".

10 For example s 168 of the Fisheries Act 1996 ("guarantee of ownership rights") has strong affinities with s 63 of the Land Transfer Act 1952 - s 63 being the core "indefeasibility" section.

11 The Courts did, however, give effect to the "custom of the sea" when considering disputed property rights in fish or whales brought before Common Law courts. A New Zealand example is the decision in Baldick $v$ Jackson (1910) 30 NZLR 343. Jackson, a whaler, who ran a shore-based station in Tory Channel, killed a whale and made it fast; however it sank, was carried out to sea, and was appropriated by the appellants. Stout CJ applied the particular custom of the New Zealand whale fishery, and found for Jackson on the basis that the whale had not been abandoned. At common law whales taken in the territorial waters of the United Kingdom or stranded ashore were regarded as royal fish and belonged to the sovereign, but in Baldick $v$ Jackson Stout CJ said this rule could have no applicability in New Zealand for two reasons: it had never been asserted in New Zealand waters by the Crown, and would in any case be contrary to the Treaty of Waitangi "for they [the Maori] were accustomed to engage in whaling." Whales are now of course protected by the Marine Mammals Protection Act 1978, but one form of whale exploitation, "whale watching" has grown to a major industry, attracting about 100,000 visitors a year to Kaikoura and worth about $\$ 30$ million a year, see generally Ngai Tahu Maori Trust Board v Director-General of Conservation [1995] 3 NZLR 553. 
Environment's recently-released and authoritative report The State of New Zealand's Environment is cautious on QMS, claiming that although it has been "hailed as very efficient" the ecological benefits are "uncertain". ${ }^{12}$

\section{THE SETTLEMENTS}

\section{A Analysis of the 1989 and 1992 Settlements}

It was the initial allocation of individual transferable quota which generated the intricate sequence of legislation and caselaw which has by no means yet run its course. The Maori fisheries issue has undoubtedly been the biggest crisis over natural resources policy in this country since the debate over coal nationalisation from 1948-51. Existing fishers received quota, but based on a minimum threshold regarded as necessary to prevent uneconomic dispersion of property rights. In Northland, where many Maori fishermen combined fishing with farming or seasonal work, the Department's initial threshold level was not met and many Maori fishermen found that they were no longer able to go fishing, unless of course they bought or leased quota from someone else. It was this very practical outcome of contemporary government policies, rather than the rediscovery of the doctrine of aboriginal title or the emergence of the Waitangi Tribunal's new jurisprudence which led to the issue first arising, although once it had it then exploded in a number of directions.

There have in fact been two fisheries settlements, one which was understood by all parties to be an interim one in 1989 and a purportedly final settlement in 1992. Both settlements are embodied in statute: the first in the Maori Fisheries Act 1989 and the second in the Treaty of Waitangi (Fisheries Claims) Settlement Act 1992. Both settlements interlocked with a set of civil proceedings against the Crown brought by a broad front of Maori plaintiff groups claiming interests in marine fisheries. The Court of Appeal distinguished between the socalled "first bracket" proceedings, the original actions of 1987 which resulted in Greig J's 1987 decisions ${ }^{13}$ to issue interim declarations halting the allocation of quota, and the "second

12 Ministry for the Environment, The State of New Zealand's Environment (Ministry for the Environment, Wellington, 1997) para 9.106.

13 The interim declarations prevented the Minister of Agriculture and Fisheries (Colin Moyle) from taking any steps to implement the quota system for jack mackerel and squid; rock lobster and paua were also affected. Arguably Greig J's interim declarations against the Crown of 30 September and 2 November 1987 were the boldest and most decisive step in the entire sequence. All of the following negotiations were conducted under the shadow of these declarations, which effectively halted the allocation of quota until a settlement of some kind was worked out. Greig J issued formal reasons for the first set of orders on 8 October (New Zealand Maori Council v Attorney-General (8 October 1987) unreported, High 
bracket" proceedings filed in 1988 by a much bigger grouping of plaintiffs. Also important in the first phase of the litigation were some interim recommendations of the Waitangi Tribunal in 1987-1988. ${ }^{14}$ The pleadings filed in the High Court raised substantial and difficult questions of law relating to the legal basis of Maori claims to fisheries and the scale and extent of such rights, including the scope of section 88(2) of the Fisheries Act which stated that "nothing in this Act shall affect any Maori fishing right". The 1989 settlement was a mere expedient. It was based on the assumption that the proceedings would at some stage be fought out in the courts and the main questions of fact and law authoritatively settled. In the meantime the government enacted into law its interim settlement offer of October 1988, by which it agreed to transfer $10 \%$ of the available quota over a 4 -year period to a new Maori Fisheries Commission (MFC). The Commission was required to establish a commercial company known as Aotearoa Fisheries Ltd, to which the Crown was to pay $\$ 10$ million, and Aotearoa Fisheries was to hold half of the quota transferred from the Crown, leaving the balance free to be leased out. Once the substantive issues at stake had been resolved, a final settlement could then be implemented in future based on the outcome of the litigation. The implementing statute was the Maori Fisheries Act 1989.

If the first interim settlement was predicated on the assumption that the litigation would in fact occur, the second was explicitly founded on an agreement that the litigation would be cancelled by statute. While the first settlement was the outcome of a wearisome and complicated history of negotiations, the second arose quite by accident: from what Wickliffe describes as the "entirely fortuitous event" of Sealords Ltd, which held $22 \%$ of the quota, coming on to the market. ${ }^{15}$ This seemed to be an opportunity too good to miss. It was agreed

Court, Wellington, CP 553/87) and an oral judgment to accompany the second set of orders on 2 November (Ngai Tahu Maori Trust Board v Attorney-General, (2 November 1987) unreported, High Court, Wellington, CP 559/87, 610/87, 614/87). Both judgments are conveniently reprinted in the Waitangi Tribunal's Muriwhenua Fishing Report, Wai 22 (Department of Justice, Wellington, 1988) 303-314.

14 These were (i) a memorandum of 10 December 1986 addressed to the Director-General of Fisheries in which the Tribunal expressed a degree of concern about its ability to form recommendations on Maori fisheries matters if the allocation of quota had already been proceeded with; (ii) a statement of 6 March 1987 by which it was announced that the Ministry of Agriculture and Fisheries legal advisers had acknowledged that "the evidence as to the extent of the fisheries was correct in all material respects" and that there was a "commercial component" to pre-European Maori fishing; and (iii) a memorandum sent to the Minister in which the Tribunal stated that "to proceed further with the issue of ITQs would be contrary to the Treaty". These three pronouncements of the Tribunal are cited and discussed by the Court of Appeal in Te Runanga o Muriwhenua Inc v Attorney-General [1990] 2 NZLR 641, 645-6.

15 Caren Wickliffe "The Co-Management of Living Resources and Maori Customary Fishing Rights" 
that the Crown would fund the purchase of Sealord in exchange for a final fishing settlement, and a Memorandum of Understanding was signed on 27 August 1992. This was followed by a series of hui, and while not everyone was happy with the proposal or the consultation process it is perhaps safest to be guided by the opinion of the Waitangi Tribunal, which concluded that "there was indeed a mandate for the settlement, provided that the Treaty was not compromised."16 A deed of Settlement was drawn up on 23 September 1992. The Crown agreed that it would pay to the Maori Fisheries Commission (reconstituted as the Treaty of Waitangi Fisheries Commission) \$150 million to advance Maori commercial fishing, thus providing the finance to allow "Maori" to proceed with a joint venture purchase of the Sealords company. The Crown also agreed that it would give "Maori" 20\% of new species quota in addition to the 10 percent already agreed to and implemented in statute by the Maori Fisheries Act 1989. In return "Maori" agreed that the settlement "shall discharge and extinguish all commercial fishing rights and interests of Maori" and that the existing civil proceedings would be discontinued; it was agreed that "Maori" would "endorse" the Quota Management system, support the implementing legislation, and that the Waitangi Tribunal would be stripped of its powers to consider commercial fisheries matters. This was all given formal effect by Treaty of Waitangi (Fisheries Claims) Settlement Act 1992, which separates commercial from customary fishing rights, and purports to wholly extinguish all Maori commercial fishing rights in exchange for the consideration set out in the deed and the Maori Fisheries Act 1992. The 1992 Act also amended the 1989 Maori Fisheries Act to allow the Commission to allocate the pre-Sealord assets (usually called the "pre-settlement assets"), ${ }^{17}$ and amended the Treaty of Waitangi Act 1975 to prevent the Waitangi Tribunal not only from inquiring into "commercial fishing or commercial fisheries" but also into the Sealords deed

unpublished paper presented to the Indigenous Land Use Agreements Conference, Darwin, 26-28 September 1995, 15 .

16 Waitangi Tribunal Fisheries Settlement Report, Wai 307 (Department of Justice, Wellington, 1992) 15 [Fisheries Settlement Report].

17 Maori Fisheries Act 1989, s 6, as amended by s 15 Treaty of Waitangi (Fisheries Claims) Settlement Act 1992. Section 6(e) as amended gave to the Commission the additional function of considering "how best to give effect to the resolutions in respect of the Commission's assets, as set out in Schedule $1 \mathrm{~A}$ to this Act..." Schedule 1A sets out resolutions made by the commission at its hui-a-tau on 25 July 1992 (that is, some months before the Sealord deed), including a resolution "that the hui endorse the decision made by the Commission to seek legislative authority to further secure the Commission's intention to allocate its assets to iwi". Essentially the Act, by a very roundabout means, empowers the Commission to allocate the "presettlement assets" to "iwi". 
itself. ${ }^{18}$ Section 43 of the Act provided for Maori representation on statutory fisheries bodies. It should be stressed that at no stage was the substantive litigation actually heard, and that the main Tribunal of fact when it comes to marine fisheries has been the Waitangi Tribunal, which released comprehensive reports on fisheries in 1988 and $1992 .{ }^{19}$

The settlements, especially the 1992 settlement, did not involve only the transfer of cash and quota entitlements. Also important was encouraging Maori to become involved in the business of fishing. To date this has mainly been done by leasing undistributed quota at a discount (although some groups continue to complain that they are not receiving a fair share) and by funding scholarships. Generally the Commission leases quota to iwi bodies at $60 \%$ below true market rates (although this still provides the Commission with a considerable income) ${ }^{20}$ The Commission now has at is disposal a very substantial bundle of cash and quota assets available for distribution, but it is important to keep this in perspective. Fishing cannot by itself be a panacea for the economic difficulties of the Maori people. Quota is of

18 Treaty of Waitangi Act 1975, s 6(7) as amended by s 40 of the Treaty of Waitangi (Fisheries Claims) Settlement Act 1992. Section 6(7) stipulates that the Tribunal shall not have jurisdiction "to inquire or further inquire into, or to make any finding in respect of: (a) Commercial fishing or commercial fisheries (within the meaning of the Fisheries Act 1983); or (b) The Deed of Settlement between the Crown and Maori dated the 23rd day of September 1992; or (c) Any enactment, to the extent that it relates to such commercial fishing or commercial fisheries". It has been argued that this language is insufficient to prevent the Tribunal from considering how the assets allocated under the 1989 and 1992 settlements ought to be allocated, but this argument was rejected by the Court of Appeal in Te Runanga o Muriwhenua $v$ Treaty of Waitangi Fisheries Commission [1996] 3 NZLR 10, 16).

19 Waitangi Tribunal Muriwhenua Fishing Report, Wai 22 (Department of Justice, Wellington, 1988); Waitangi Tribunal Ngai Tahu Sea Fisheries Report, Wai 27 (Department of Justice, Wellington, 1992). Neither report actually contains much empirical data about the scope of Maori deep-sea fishing. Both reports, especially the former, were intended as key statements on fisheries at crucial stages in the negotiations. For the most part the Muriwhenua Fishing Report is a detailed study of national fisheries legislation and a discussion of why the Tribunal believed to be contrary to the principles of the Treaty of Waitangi. There was also some discussion of overseas case law, notably the famous Federal District Court decision in United States $v$ State of Washington (1974) 384 F Supp 312 (WD Wash) and the decision of the British Columbia Court of Appeal in $R v$ Sparrow (1986) 36 DLR (4th) 246. In Muriwhenua the Tribunal's main findings of fact were that there was "a commercial component in pre European tribal fisheries through 'gift exchange'", and that gift exchange "was capable of adaptation" and indeed "adapted and developed to trade in Western terms", 200. The Tribunal's findings of law are, in the present writer's view at least, very confusing, based on a difficult distinction between the principles and the literal terms of the Treaty: see Muriwhenua, 211, 218.

20 See Treaty of Waitangi Fisheries Commission/Te Ohu Kai Moana "Annual Report, 1994" [1994] AJHR C19, 11. 
little value without the infrastructure of boats, gear, technical training and access to markets. Prior to 1986, after all, there were no quota and anyone could go fishing, to no particularly obvious Maori economic benefit. The New Zealand fishing industry and fish stocks are not by themselves large enough or valuable enough to solve the current economic difficulties facing the Maori people.

\section{B Statutory Pragmatism Triumphant}

The 1989 and 1992 agreements are classic examples of the historically dominant New Zealand political-constitutional system of "statutory pragmatism". This tradition involves two aspects: a tendency for deals to be done behind the scenes based on current political configurations rather than considerations of principle, and the tendency for these deals to be enshrined in statute to give them the force of law. Nowhere is this more true than in the area of the legal relationship between Maori and the state. It is often said that the common law, or British law, has been imposed on Maori, which may be true enough, but this often has little relevance to the law which really matters in the area, which is entirely statutory and produced locally, often as a result of deals and negotiations. It is hard to see the Maori Fisheries Act 1989 as the imposition of a culturally-distinct foreign form of law on Maori. On the contrary, it was evolved here, was the product of negotiations, and owes nothing to the common law. Perhaps it might be said that it is based on the underlying sovereignty of Parliament, an imported legal theory, but this seems to be a theory that all parties accept: it was in fact expected that the settlement would be enshrined in statute, and that this would be the action which made it binding.

Statutory pragmatism can lead to some very troubling consequences when the initial deal is done not on behalf of some defined descent group, but purportedly on behalf of all "Maori". The Sealords deed in fact could not have stood alone as a legally enforceable contract without the benefit of statute. Looking like a contract, in fact it was nothing of the sort. In Te Runanga o Wharekauri Rekohu Ltd $v$ Attorney-General ${ }^{21}$ where the legality of the deed was challenged, Cooke $P$ found himself unable to see the deed as a simple contract, and described it, very aptly, as "a compact of a political kind, its subject-matter so linked with contemplated Parliamentary activity as to be inappropriate for legal rights". The clause by which the government pledged itself to introduce the implementing legislation was obviously unenforceable: if the government changed its mind no court could conceivably give a remedy and compel the government to introduce the necessary legislation into parliament. But then

21 [1993] 2 NZLR 301 (CA). 
this did not matter, because it was never contemplated that the deed would be binding and enforceable of itself. The purpose of the deed was to legitimise the introduction of a statute; and although the deed was not binding on everyone, the implementing statute certainly was. But whether there was a sufficient "mandate" for the implementing legislation was, in the Court of Appeal's view, a "political question" for "political judgment"; the "Court is not concerned with such questions". ${ }^{22}$

Neither the government nor the Maori negotiators nor the Courts ever pretended that the Sealords deed was binding on all Maori once it had been signed. How could it be? There was no way even of reliably judging the amount of Maori assent: ${ }^{23}$

All that can be safely said is that the deed was negotiated by some responsible Maori leaders and has significant Maori support but also significant Maori opposition.

The opposition was demonstrated by the legal challenges mounted by critics in the courts and in the Waitangi Tribunal, in both instances without success. ${ }^{24}$ In the Court of Appeal opponents had to adopt the hopeless course of trying to persuade the Court to restrain the Minister from introducing the legislation into parliament, which was inevitably rejected. ${ }^{25}$ Opponents of the deal fared little better in the Waitangi Tribunal, which was generally cautiously supportive of the settlement, accepted that adequate consultation had taken place, but which declared itself opposed to legislative abolition of rights protected by the Treaty of Waitangi. ${ }^{26}$

\section{DISTRIBUTION OF THE TRANSFERRED ASSETS}

The principal current issue is the means of asset allocation to be employed by the Treaty of Waitangi Fisheries Commission (as the Maori Fisheries Commission was renamed in 1992),

22 Te Runanga o Wharekauri Rekohu Ltd 309.

23 Wharekauri, 307.

24 Te Runanga o Wharekauri Rekohu Inc v Attorney-General [1993] 2 NZLR 301; Waitangi Tribunal, The Fisheries Settlement Report Wai 307 (Department of Justice, Wellington, 1992). These two decisions were released on successive days, the Court of Appeal decision on 3 November 1992 and the Waitangi Tribunal's report on 4 November.

25 See Te Runanga o Wharekauri, above n 22, 307-308.

26 Fisheries Settlement Report, above n 16, 23-24. In terms of asset allocation the Tribunal's conclusion was that the scheme "should not be based on treaty principles alone" but on "broad considerations of what is tika, or fair, in all the circumstances", Fisheries Settlement Report, 21. 
an extremely difficult problem as it goes to the very core of what the settlements were about and who they were supposed to be with. As Lord Goff noted Treaty Tribes Coalition v Urban Maori Authorities Maori have found the task of dividing the fisheries resource to be "an extremely challenging process". ${ }^{27}$

Much was left ambiguous with the Sealords deed, which was drawn up with "Maori", without further explanation, and which left to one side the question whether "Maori" was supposed to mean some kind of federation of autonomous iwi or whether it meant simply a sector of the general population of the country differentiated by an ethnic criterion. Was the settlement for the benefit of everyone who happened to be Maori, or was it intended as a restoration of property rights to specific groups based on territory, historic involvement in marine fishing or some other criterion of specific, tribal connection to the resource? The Commission, for its part, now finding itself on the receiving end of civil proceedings, has argued that Maori living in urban areas must belong to some iwi ("tribe") if they can be meaningfully said to be "Maori" at all, and it is not at all the case that urban Maori will not benefit from a distribution of assets to "iwi". Rather, the initial distribution will be to iwi, who can then apportion interests to the members of the iwi wherever they happen to live. The claim of the separate Urban Maori Authorities (UMAs) to represent Maori living in urban areas is itself highly contestable. ${ }^{28}$

However the current struggle is not only between "urban" and "tribal" Maori. One of the more vociferous objectors to the Commission's "mana whenua/mana moana" 29 model was

27 [1997] 1 NZLR 513, 517 (PC).

28 Above n 27, 517 per Lord Goff. For one thing, some "urban" Maori simply happen to belong to iwi whose traditional territory now falls within urban areas: examples are Ngati Whatua of the Tamaki isthmus or Ngati Toa based at Porirua. Ngati Toa certainly do see themselves as an "iwi" rather than as "urban Maori".

29 By which rights are allocated on the basis of coastline contiguous to tribal rohe (territories). This creates some anomalies, at least arguably. The relatively small Ngai Tahu tribe occupied most of the entire South Island, much of which was unsuitable for Maori horticulture. A purely mana whenua/mana moana allocation model would place a huge section of the transferred assets into the hands of one small descent group which represents probably less than $5 \%$ of the Maori population. The problem is: is this a problem? What is the settlement about? Lifting "Maori" out of their economic plight or restoring property to "tribes"?

The most recent proposal for allocation of the pre-settlement (that is, 1989) assets is set out in Te Ohu Kai Moana/Treaty of Waitangi Fisheries Commission "Proposed Allocation Consultation Document" (Wellington, July 1997). This is essentially a modified mana whenua/mana moana proposal, by which 
the Te Runanga o Muriwhenua Incorporation, representing the tribes of the Far North, the group who had initiated the original proceedings in the first place, a group who actually went fishing and had fishing boats, and who had still failed to benefit from the settlements; in fact who were, economically speaking, worse off than ever. The anomalies were explained by the Court of Appeal: ${ }^{30}$

It is claimed that the population of Muriwhenua is 18,492, that of Ngai Tahu 22,269; and that Muriwhenua, although heavily dependent on fisheries, unlike Ngai Tahu has few other resources as well as a large number of unemployed. Sharp discrepancies are alleged in the previous lease rounds, and it is said that the application of a mana whenua, mana moana model would give the Muriwhenua tribes an average of $\$ 203.92$ per capita as compared with $\$ 4533.24$ for Ngai Tahu.

One can certainly see why the Muriwhenua tribes feel aggrieved. ${ }^{31}$ In the current litigation the four urban Maori authorities ${ }^{32}$ and Te Runanga o Muriwhenua were also supported by Te Waka Hi Ika o Te Arawa, an incorporated society representing Arawa fishers and the Arawa Maori Trust Board. ${ }^{33}$ The Commission was supported, on the other hand, by the Treaty Tribes Coalition (which includes Ngai Tahu and Ngati Kahungunu), Tainui Waka Fisheries, Te Runanga o Ngati Porou and the Te Iwi Maori Trust Board. Those favouring a distribution on an iwi/tribal basis are themselves divided as to how this should be done. In brief, the issues now at stake are particularly difficult and raise quite fundamental

inshore quota will be allocated according to a "coastline formula", and deepwater quota will be allocated $60 \%$ on the basis of the coastline formula, and $40 \%$ on the basis of iwi population.

30 Te Runanga o Muriwhenua v Te Runanganui o Te Upoto o Te Ika Association Inc [1996] 3 NZLR 10, 16.

31 A possible response is that the particular grievances of Muriwhenua fishermen arising out of the initial allocation of quota is conceptually a quite distinct matter from a Treaty of Waitangi-based global settlement of commercial fishing rights. As the settlement was of a higher-order, constitutional basis, so must the assets received be distributed in a coherent and constitutional manner, and not on the basis of particular local grievances arising under the former system.

32 There are two Auckland Urban Maori authorities (UMA), Manukau Urban Authority Inc and Te Whanau o Waipareira Trust, one from Wellington, Te Runanganui o Te Upoko o Te Ika Association, and one from Christchurch, Te Runanga o Nga Mata Waka Inc.

33 The Arawa confederation, one of the largest and most important groupings within Maori society, is made up of a number of descent groups mostly living inland around the Rotorua lakes, but who had a small strip of coastal territory around Maketu. Any allocation of assets based on coastal territory would disfavour Arawa. 
questions about the purpose of the 1989 and 1992 settlements and indeed the very nature of Maori society today.

The current litigation has focused on the distribution of the pre-settlement assets, that is the corpus of assets transferred under the 1989 interim settlement, made up of quota, cash, and shares in a company known as Moana Pacific Ltd. In Te Runanga o Muriwhenua Anderson $\mathrm{J}$ had decided that a preliminary question in judicial review proceedings brought by the Area One Consortium and four urban Maori authorities should be set down for hearing before the substantive case began. ${ }^{34}$ The question was:

Is the Treaty of Waitangi Fisheries Commission, in the exercise of its power to allocate presettlement assets, required to allocate those presettlement assets to iwi.

The Court of Appeal allowed the appeal, finding that "no useful purpose" could be served by the determination of this preliminary point. In coming to that view the Court of Appeal considered at some length the meaning of the term "iwi". ${ }^{35}$ Controversially, the Court held that iwi meant, simply, "people of the tribe", and accordingly the Commission had to make separate provision for urban Maori. ${ }^{36}$ In determining the meaning of "iwi" the Court considered six sources: the Maori text of the Treaty of Waitangi, the Waitangi Tribunal's Fisheries Settlement Report of 1992, Williams' Maori Dictionary (the most authoritative

34 This case is procedurally complex. Judicial review proceedings were filed by the Area One Consortium and four Urban Maori Authorities against the Treaty of Waitangi Fisheries Commission and the Crown, alleging bias and breach of statutory duty by the Commission. The Treaty Tribes Coalition, Te Runanga o Ngati Porou, and Te Waka Hi Ika o Te Arawa also brought proceedings. Then on 30 June 1995 Anderson J ordered the preliminary question (see text) be decided before trial. It was this order which was appealed by the Area One Consortium (one of the plaintiff groups) to the Court of Appeal. There were also separate proceedings before Ellis J following on from claims in the Waitangi Tribunal lodged by the Area One Consortium and the Urban Maori Authorities. The Tribunal's decision to proceed with inquiring into these claims led to judicial review proceedings against the tribunal being filed in the High Court by the Treaty of Waitangi Fisheries Commission and the Treaty Tribes Coalition. The plaintiffs argued here that the Tribunal could not hear the claim because of s 6(7) of the Treaty of Waitangi Act 1975, inserted by the Treaty of Waitangi (Fisheries Claims Settlement) Act 1992. Ellis J held that s 6(7) did not prevent from the Tribunal from hearing the claim; but on appeal the Court of Appeal held that the section was effective to oust the Tribunal from inquiring into the issue (see Te Runanga o Muriwhenua $v$ Te Runanganui o Te Upoko o Te Ika [1996] 3 NZLR 10, 16). This point was not appealed to the Privy Council.

35 Te Runanga o Muriwhenua v Te Runanganui o Te Upoko o Te Ika [1996] 3 NZLR 10.

36 Te Runanga o Muriwhenua v Te Runanganui o Te Upoko o Te Ika, 19-20. 
dictionary of the Maori language), the 1992 Act, the 1992 Sealords deed itself, and the submissions and memoranda of counsel. ${ }^{37}$ What was noticeably lacking was any expert evidence on the record from those qualified to speak about the nature of Maori society, the Maori language, or Maori customary law. The Court of Appeal's reliance, at least in part, on the Waitangi Tribunal, shows once again the extent to which the Tribunal has assumed the role of the primary tribunal of fact in the absence of any testimony in the ordinary courts. In fact, in this instance, the question was not comprehensively discussed in the Waitangi Tribunal either, and it is difficult to take from the Tribunal's comments in its Fisheries Settlement Report any notion that the concept of "iwi" could be broadened in the way the Court of Appeal suggests. ${ }^{38}$

The Court of Appeal decision was appealed to London by some of the parties. The Privy Council's decision, released on 16 January 1997, is reported as Treaty Tribes Coalition, Te Runanga o Ngati Porou and Tainui Maori Trust Board v Urban Maori Authorities. ${ }^{39}$ The appeal was allowed in part and the preliminary question was remitted to the High Court and reformulated. The High Court was directed to determine whether the pre-settlement assets should be distributed to "iwi", and, if so, whether "iwi" meant "only traditional Maori tribes". The case was argued before Patterson J whose decision was released on 4 August $1998 .{ }^{40}$ The Crown took a neutral role in the proceedings, an intriguing stance: it would have been interesting to know what the government thought it was agreeing to in 1992. For once, there was a substantial body of evidence before the Court: 74 affidavits from some 64 deponents were filed, 44 of whom were cross-examined.

37 Te Runanga o Muriwhenua v Te Runanganui o Te Upoko o Te Ika, 17-19.

38 The tribunal discusses the term "iwi" in its Fisheries Settlement Report, above n 16, 12-14. The Tribunal's main point is that the main structural unit of Maori society was not the iwi ("tribe") but rather the hapu (sub-tribe or clan); nevertheless some matters of particular importance had to be decided at iwi level. With European settlement, "iwi structure became more necessary, significant and permanent" and "the current wisdom appears to be that matters of common policy affecting the people generally, should be determined or ratified at an iwi or iwi-whanui plane" Fisheries Settlement Report 13.

39 [1997] 1 NZLR 513.

40 Te Waka Hi o Te Arawa and others v Treaty of Waitangi Fisheries Commission (4 August 1998) unreported, High Court, Auckland Registry, CP 395/93 (Wgtn) Anderson J. 
Patterson J found that the basic unit of traditional Maori social structure was not the iwi (tribe) at all, but the hapu (sub-tribe, clan): ${ }^{41}$

[R] esource management and welfare functions were typically carried out at whanau or hapu level and not iwi level. Often an iwi had no rigid structure and hapu entered and left collectives as needs dictated.

Fishing rights were held by hapu, not iwi, and, accordingly, "it is, in the main, rights which were vested in hapu which were infringed by the QMS and which the Crown has now abrogated and taken away".42 More recently, and partly in consequence of government policies, said Patterson J, it is the iwi which has come into prominence. At the same time, however, the Maori population has become largely urbanised, concentrated to a large extent in Auckland, and to a growing degree (it would seem) remote from iwi links. Patterson J referred to the 1996 census which showed a total of 597,414 Maori, 70\% of whom lived outside tribal territories (rohe); 112,566 people identifying as Maori indicated that they did not know which iwi they belonged to and another 40,917 did not specify their iwi. ${ }^{43}$

The precise question before the Court involved the interpretation of the Maori Fisheries Act, in particular section 6(e), which gave to the Commission the additional responsibility of considering "how best to give effect" to certain resolutions of a Hui-a-Tau of 25 July 1992 incorporated as a schedule to the 1992 Act. Resolution 1 was that the Hui-a-Tau endorse the Commission's decision to seek legislative authority in order to allocate its assets to "iwi". Patterson J carefully considered the context of both the legislation and the Hui-a-Tau itself and concluded that the Commission was required by law to allocate its assets to "iwi".

The second problem was the meaning of "iwi". Patterson J saw the issue as essentially one of statutory interpretation (rather than as the incorporation of Maori customary law): ${ }^{44}$

41 Te Waka Hi o Te Arawa, 28.

42 Te Waka Hi o Te Arawa, 26.

43 Te Waka Hi o Te Arawa, 34-5.

44 Te Waka Hi o Te Arawa, 72. Proof of a point of Maori customary law, whether incorporated by statute, as an aspect of the doctrine of aboriginal title (as in Te Weehi v Regional Fisheries Officer [1986] 1 NZLR 680) or simply on the basis that Maori customary law is part of the common law of New Zealand (as in Public Trustee v Loasby (1908) 27 NZLR 801 (SC); Heneiti Rirerire Arani v Public Trustee (1919) [18401932] NZPCC 1; and see also Chilwell J's dicta in Huakina Development Trust v Waikato Valley Authority [1987] 2 NZLR 188, 215 (HC)) is a different process from interpreting Maori words in a statute. Proof of customary law requires expert evidence from those qualified in the customary system, as in Loasby 
A complication is that, for present purposes, the word is a Maori word used in an English statutory context.

In interpreting the provision Patterson J followed Lord Wilberforce's approach to interpretation of foreign words in statutes in Fothergill v Monarch Airlines Ltd: ${ }^{45}$

I am not willing to lay down any precise rule on this subject. The process of ascertaining the meaning must vary according to the subject matter. If a Judge has some knowledge of the relevant language, there is no reason why he should not use it... There is no reason why he should not consult a dictionary if the word is such that a dictionary can reveal its significance; often of course it may substitute one doubt for another.

The key point is that interpreting foreign words in English or New Zealand statutes is a somewhat more flexible process than interpreting statutorily-incorporated foreign law, although the distinction might often be difficult to draw. Is "iwi" merely a Maori word or an incorporation of Maori law? Patterson J treated it as the former, and took into account dictionary definitions, the views of the Waitangi Tribunal as an expert body, and the corpus of evidence before the court. He concluded: ${ }^{46}$

The above considerations lead to the conclusion that... "iwi" means traditional Maori tribes in the sense that a tribe includes all persons who are entitled to be a member of it because of kin links and genealogy.

The UMAs were not iwi, although, of course, "many, if not all, of their Maori members are entitled to share in the benefits of the settlement". ${ }^{47}$ The Commission was not, therefore, required to make any separate provision for the UMAs.

Immediately after the decision Maori Affairs Minister Tau Henare called on Maoridom to allow the fisheries settlement assets to proceed without further court action, but representatives of the UMAs nevertheless announced that they were likely to appeal. ${ }^{48}$ The

which followed standard English and British colonial practice as to proof of customary law. However the distinction between a statutory incorporation of a Maori word and of a rule of Maori customary law is a very fine - the example of "iwi" being a case in point.

45 Fothergill v Monarch Airlines Ltd [1981] AC 251, 273.

46 Te Waka Hi o Te Arawa, 79.

47 Te Waka Hi o Te Arawa, 81.

48 "Let Fisheries assets flow, Henare urges Maoridom", The Dominion, Wellington, August 51998. 
next stage in the process is for the Treaty of Waitangi Fisheries Commission to finalise its draft allocation model, which is required to be presented to the Minister in early 1999. Given that although the UMAs have lost the most recent round in the High Court but nevertheless achieved a remarkable success in the Court of Appeal in 1996, further challenges to the Commission's allocation model seem inevitable.

\section{CUSTOMARY FISHING}

\section{A The 1992 Legislation and Customary Fisheries}

As if the complexities of the 1989 and 1992 settlements were not enough, the law is further confused by the quite different legal regime now applying to customary fisheries, some of which dates from the 1992 implementing legislation and of which some predates it. ${ }^{49}$

Of particular note was 10(c) of the 1992 Settlement Act requiring the Minister to recommend that the Governor-General make regulations to recognise and provide for (i) customary food gathering; and (ii) protection of places which are of customary food gathering importance. ${ }^{50}$ Section 34 of the 1992 Act empowered the making of regulations recognising and providing for "customary food gathering by Maori", the "special relationship between tangata whenua and places of importance for customary food gathering"151 and also empowered the Minister "to declare any part of New Zealand fisheries waters to be a maitaitai reserve". ${ }^{52}$ (The regulation-making power is now contained in section 186 of the Fisheries Act 1996.) A certain degree of local self-management was recognised by section 34 of the 1992 Act which allowed the Minister to empower local Maori communities to make "bylaws restricting or prohibiting the taking of fish, aquatic life, or seaweed". 53 Further

49 This paper will not discuss the special lakes settlement agreements and their various implementing statutes, some of which made particular provision for customary taking of indigenous fish species. For examples s 14 (2) of the Native Land Amendment and Native Land Claims Adjustment Act 1992 [Lake Taupo] reserved "to the Natives the right to fish for and catch for their own use any indigenous fish in the said lake".

50 Treaty of Waitangi (Fisheries Claims) Settlement Act 1992, s 10(c); see also Fisheries Act 1996 s 186 (1).

51 Treaty of Waitangi (Fisheries Claims) Settlement Act 1992, s 34(1), amending s 89(1) Fisheries Act 1983, now Fisheries Act 1996, s 186 (1).

52 Treaty of Waitangi (Fisheries Claims) Settlement Act 1992, s 34(1). amending s 89 (1) Fisheries Act 1993, now Fisheries Act 1996, s 186(2)(b) and (c).

53 Treaty of Waitangi (Fisheries Claims) Settlement Act 1992, s 34(2), amending s 89 (1) of the Fisheries Act 1983, now Fisheries Act 1996, s 186 (2)(d). 
protection was conferred on taking fish for marae consumption. ${ }^{54}$ Regulations aside, the legislation explicitly stated that the defence of customary fishing was no longer available in criminal proceedings and was not actionable civilly. ${ }^{55}$ The making of the regulations has proved to be an extremely difficult and fraught process, and the main customary fishing regulations for the North Island are still not yet implemented at the time of writing. ${ }^{56}$

\section{B The McRitchie Case}

The fish stocks, native and introduced, found in New Zealand's internal waterways have long been managed under a separate legal regime. Part V of the Fisheries Act 1983 dealt with freshwater fisheries. Acclimatisation societies were made responsible by section 71 for the protection, management and enhancement of all acclimatised fish species, and the conservation of all indigenous freshwater species. In 1990, however, the regulation of freshwater fisheries was severed from the Fisheries Act 1983 and transferred, by the Conservation Law Reform Act 1990, to the Conservation Act 1987. To make the law consistent with the Fisheries Act, however, section 26ZH of the Conservation Act 1987 was added, which states that "nothing in this Part of the Act shall affect any Maori fishing rights".

In McRitchie the respondent was charged under section 26ZI(1)(a) of the Conservation Act with fishing for a sports fish (trout) without holding a current licence. He raised as his defence section $26 \mathrm{ZH}$, and the case is thus strikingly similar to earlier cases invoking section 88 (2) as a defence to prosecutions under the Fisheries Act (section 88(2) itself was, of course, removed as an outcome of the 1992 settlement). ${ }^{57}$ In a very lengthy and carefully analysed

54 Treaty of Waitangi (Fisheries Claims) Settlement Act 1992, s 34(2), amending s 89(1) Fisheries Act 1983, now Fisheries Act 1996, s 186(2)(e).

55 Treaty of Waitangi (Fisheries Claims) Settlement 1992, s 10(d). In Manukau v Ministry of Fisheries, (29 July 1998) unreported, High Court, Auckland Registry, M 984/97 Salmon J it was argued inter alia that the defence of customary fishing for marine species could still apply as the relevant regulations were not in place; but this was rejected as incorrect and clearly contrary to the wording of s $10(\mathrm{~d})$ of the Treaty of Waitangi (Fisheries Settlement) Act 1992. In the absence of comprehensive customary regulations as envisaged by the 1992 Act it was possible to rely only on Regulation 27 of the Fisheries (Amateur Fishing) Regulations 1986, which allow for taking for "hui, tangi or traditional noncommercial fishing use" as approved by the Director-General. Salmon J held that the actions of the applicants did not fall within the scope of reg 27.

56 October 1996. The Fisheries (South Island Customary Fishing) Regulations 1998 were made on 20 April 1998.

57 For a discussion of some of the earlier caselaw see R P Boast "Treaty Rights or Aboriginal Rights?" [1990] NZLJ 32. 
judgment Judge Becroft accepted the defence and McRitchie was acquitted; the prosecuting body, the Taranaki Fish and Game Council, appealed by way of case stated. One issue was whether section 10(d) of the Treaty of Waitangi (Fisheries Claims) Settlement Act applied to freshwater fisheries; the High Court concluded that it did not, ${ }^{58}$ and thus the defence of customary fishing remained open in respect of prosecutions relating to freshwater fishing. The case raised the interesting, perennial and perhaps unanswerable question of what is meant by a "Maori fishing right". The respondent argued that such a right was not limited as to species, but related more to fishing places and purposes, and could thus plausibly extend to an introduced fish stock such as trout. The opposing view was that the right was focused on fish stocks rather than the activity of fishing. The High Court found however that the essential point was that trout fishing had always been "regulated by law":59

It is the facts first that the controlling legislation predates the introduction of the fish and second that regulatory control has continued in some form in respect of trout to the present that in our view distinguish this case from others. The legislature must have been aware of the presence of indigenous fish in freshwaters, but successive legislation had the effect that there never was a time when trout or salmon were available without control to those who otherwise were free or had rights to fish in fresh water.

With respect, it is difficult to see that emphasising the statutory control of trout allows the core question, the scope of section $26 \mathrm{ZH}$, to be sidestepped in the way that the High Court seems to suggest. The High Court's view is, in effect, that the phrase "any Maori fishing rights" cannot include statutorily controlled introduced fish stocks because to include them would not be consistent with parliament's presumed intention in 1990. But why should that be? The legislature may, with equal plausibility, be said to have decided exactly the opposite. All that happened in 1990 was that the section 88(2) phraseology, much fought-over at the time, was carried over to the Conservation Act unchanged and with all the core conceptual problems unresolved. The real, and, with respect, inescapable problem is that of what is meant by a "Maori fishing right", which raises the very issues so carefully grappled with by

58 Taranaki Fish and Game Council v McRitchie, (14 May 1998) unreported, High Court, Wellington AP 19/7 (Wanganui) Neazor and Greig JJ, 27. This was because the bar applied only to non-commercial fishing for species etc. "that are subject to the Fisheries Act 1983" (Treaty of Waitangi (Fisheries Claims) Settlement Act 1993 s 10); freshwater fisheries were excised from the Fisheries Act 1983 by the Conservation Law Reform Act 1990, and thus were not subject to the Fisheries Act 1983 when the 1992 legislation was enacted.

59 Taranaki Fish and Game Council, 23. 
Judge Becroft at first instance - such as whether the right derives from the Treaty of Waitangi or aboriginal title, whether that matters, whether the content of the right is affected by the socalled "right to development" and so on. ${ }^{60}$ It could even be argued, in fact, that if the right derives from common law concepts of native title, the only real point is whether such right has been extinguished, which arguably it has not been. Nor does the High Court's approach satisfactorily resolve the question whether the right is to be understood in terms of fish stocks or, alternatively, of fishing places and purposes. The right contended for is not a right to catch trout, but a right to go fishing in a particular place for a particular purpose. Whether the High Court decision in McRitchie has satisfactorily settled the problem of the scope of section $26 \mathrm{ZH}$ may be doubted. ${ }^{61}$ The case has been appealed to the Court of Appeal. ${ }^{62}$

\section{Taiapure-Local Fisheries and Mataitai Reserves}

Protection of customary fishing rights by means of the establishment of reserves has long been a feature of New Zealand law. ${ }^{63}$ There are now two main categories of reserve,

60 Judge Becroft's decision is reported at [1997] DCR 446.

61 The High Court's approach may be contrasted with the leading US decision, this being the Ninth Circuit decision in United States $v$ State of Washington (Phase II) (1984) 759 F 2d 1353. Here the Federal Court of Appeals, Ninth circuit upheld Judge Orrick's ruling at (1980) 506 F Supp 187 rejecting the state's claim that first-generation hatchery trout should be excluded from tribal allocation of fishing rights deriving from a Treaty. The establishment of hatcheries, in Judge Orrick's view, was necessary only because of the "commercialisation of the fishing industry and the degradation of the fishing habitat caused primarily by non-Indian activity in the case area": see (1980) 506 F Supp 187, 203. This is not exactly analogous to New Zealand where trout is a wholly introduced stock, but it seems to be the case that such introduced stocks into New Zealand's waterways have impacted severely on indigenous species (see generally The State of New Zealand's Environment, above n 6, ch 9, 85-94 ). On a number of occasions Maori petitioned government to stop the introduction of exotic fish stocks: see R R Strickland "Pre-European transfer of smelt in the Rotorua-Taupo area' (1993) 23 Journal of the Royal Society of New Zealand 13. Arguably McRitchie was fishing for trout because there were no indigenous fish to catch, which if so would make the US authorities very much in point. To some degree statute law has recognised special Maori interests in regard to introduced fish stocks. Under s 14(9)(c) of the Native Land Amendment and Native Land Claims Adjustment Act 1926 members of the Tuwharetoa tribe were entitled to free fishing licences for "imported fish"; and by s 15 (2) of the same Act the Tuwharetoa Maori Trust Board was entitled to receive $50 \%$ of the annual income received from fishing licences issued in respect of Lake Taupo.

62 [Editor's Note] Subsequent to submission of the article, the appeal was dismissed, McRitchie $v$ Taranaki Fish and Game Council (24 November 1998) unreported, CA 184/98.

63 A number of reserves were set aside under s 439 of the Maori Affairs Act 1953, these being, coures, areas that were already Maori freehold or Maori customary land. The current provision is now s 338(1) 
taiapaure-local fisheries and mataiatai reserves. Taiapure-local fisheries are the Cinderella of Maori customary fisheries. They began life with the Maori Fisheries Act 1989. That Act, of course, implemented the interim settlement proposal of October 1988. It also introduced a new regime for taiapure-local fisheries, a category of Maori fishing reserve. Such reserves can only be made in littoral coastal waters or estuarine waters and are established by means of a very cumbersome procedure involving a public inquiry conducted by a judge of the Maori Land Court. ${ }^{64} \mathrm{Few}$ have been established. The 1992 Act, however, made provision for "mataitai reserves", which are much easier to establish, and which can be made in both coastal and internal waters. Procedural matters and location aside, quite what the differences are between the two categories of reserve is something of a puzzle. The Ministry of Maori Development sees taiapure as "local fishery areas, in estuarine or coastal waters, which are of special significance to hapu or iwi", while mataitai reserves "are areas of traditional

of Te Ture Whenua Maori 1991. This allows the Chief Executive of Te Puni Kokiri to set aside on the recommendation of the Maori Land Court "any Maori freehold land or General land" as a Maori reservation for a number of purposes, including landing places and fishing grounds. (The scope of the reference to "general land" in this provision is unclear; certainly parliament cannot have intended to give the Maori Land Court power to confiscate any general land and set it apart as a Maori reservation.) It was also theoretically possible for Maori fishing reserves to be set aside under former fisheries legislation, although in practice few were.

64 The provisions for taiapure-local fisheries are now contained in Part IX of the Fisheries Act 1996. By this procedure the Governor-General may, by order in council, "declare any area of New Zealand fisheries waters (which waters are estuarine waters or littoral coastal waters) to be a taiapure-local fishery. Any person can present to the chief executive of the Ministry a proposal for the establishment of a taiapure-local fishery ( $\mathrm{1}$ 177). This is then referred to the Minister; if the Minister "agrees in principle with the proposal" (s 178(3)) it is published in the Gazette and there are broad rights of public objection. There is then a public enquiry conducted "by a tribunal consisting of a judge of the Maori Land Court" (s 181) which reports to the Minister, who then decides whether to proceed with the establishment of the taiapure-local fishery. The Minister then appoints a committee of management "on the nomination of persons who appear to the Minister to be representative of the local Maori community". The committee can recommend the making of regulations, but no regulations shall provide for any person to be refused access to such a taiapure-local fishery, or to be required to leave or cease to use such a fishery "because of the colour, race, or ethnic or national origins of that person" (s 185). In view of their cumbersomeness, and the very limited rights of self-management they actually confer, taiapure-local fisheries have not preferred a very popular device. As far as the writer is aware four have been established: see Fisheries (Maketu Taiapure) Order 1996; Fisheries (Palliser Bay Taiapure) Order 1995, 1995 SR 144; Fisheries (Porangahau Taiapure) Order 1996; Fisheries (Waikare Inlet Taiapure) Order 1997. 
importance to tangata whenua" which can "exist within taiapure". 65 Presumably the provisions relating to taiapure-local reserves were left in place in order to continue to safeguard such reserves already established or in the process of being established. It might also be possible to utilise the heritage protection provisions of the Resource Management Act 1991 to protect customary fishing. ${ }^{66}$

\section{CONCLUSION}

The legal interests of the tribes in respect of fisheries, must, for the purposes of the official New Zealand legal system, be sourced in something, and the most likely 'something' must be the Treaty of Waitangi. ${ }^{67}$ This emerges clearly from the 1992 Deed of Settlement and from the $1989^{68}$ and 1992 Acts. ${ }^{69}$ This essay has argued that for the purposes of the fisheries settlements of 1989 and 1992 the main, indeed effectively the only, tribunal of fact has been the Waitangi Tribunal. As the Tribunal's statutory mission is to determine whether acts or omissions of the Crown are contrary to the principles of the Treaty the factual material on the record, such as it is, can also be taken to be focused on the Crown's Treaty-based obligations, although whether the claim to a marine commercial fishery has been satisfactorily established by the Muriwhenua Fishing Report (1988) and the Ngai Tahu Sea Fisheries Report (1992), is, I believe, at least arguable.

What is the government's "Treaty" policy about: what are the goals, the objectives, the aspirations? The answer is hard to discern, especially in the case of fisheries. The current situation has arisen through configurations of politics and power, a game of move and countermove, rather than through the coherent articulation of a principled claim and the coherent development of a response. Maori claimants successfully adopted a three-pronged strategy of litigation in the ordinary courts, articulating claims in the Waitangi Tribunal, and

65 Ministry for Maori Development/Te Puni Kokiri "Nga Kai o te Moana: Kaupapa Tiakina" (Wellington, 1993) 11.

66 See Resource Management Act 1991, s 181(1).

67 The common law doctrine of Native or Aboriginal title is the other obvious candidate as far as the official legal system is concerned. As noted in the text, however, the 1989 and 1992 settlements and their implementing enactments explicitly invoke the Treaty of Waitangi.

68 The Act is described in its long title as an Act "to make better provision for the recognition of Maori fishing rights secured by the Treaty of Waitangi".

69 See Treaty of Waitangi (Fisheries Claims) Settlement Act 1992, Recitals, especially cls (a), (c), (d), (f), (j) and (k) and s $10(\mathrm{a})$ and (b). 
direct negotiations with the Crown. It is difficult to avoid the conclusion that without the early successes in the ordinary courts, sufficient to halt the government's programme of quota allocation in its tracks, little progress could have been made. With the injunctions in place, and the substantive proceedings looming, a deal had to be struck, and indeed was. The necessity for a deal and the re-emergence of statutory pragmatism was due to legal uncertainty. At no stage during the proceedings were any of the substantive legal questions definitively answered. Although there is a considerable volume of caselaw on Maori fisheries since 1986, at the appellate level it mostly deals with a sequence of disconnected interlocutory points. Two main substantive matters seem to have been established, these being that, statute aside, common law protection of Maori fisheries certainly does exist, and that the expression "iwi" means traditional Maori tribes and not new entities such as urban Maori authorities. Everything else is uncertain. In particular the Courts have been unsuccessful in clarifying the sources and scope of the rights protected by section 88(2) of the 1983 Act, a point which remains unresolved at present, and which is still, as a consequence of the amendment of the Conservation Act in 1990, of some practical importance.

The fisheries settlement also illustrates the New Zealand policitico-legal system's propensity to create intricate edifices of statute. The situation is particularly confused with respect to customary fisheries. All customary fisheries are unaffected by the 1992 Settlement legislation, but freshwater customary fisheries remain affected by a recasting of the old section $88(2)$ in section $26 \mathrm{ZH}$ of the Conservation Act 1987. Here the core conceptual difficulties still remain.

Most fundamentally of all, there is the problem of how the Crown's legal obligations in respect of "Maori" are to be understood. Are "Maori" claims advanced on a basis of ethnicity, or, rather - as O'Regan insists - are they dependent on public-law relationships between the Crown and iwi? This is the core problem which underpins the cases grappling with the meaning of "iwi" as set out in the 1992 legislation. If the Crown's obligations are to Maoridom as such, what purpose can be served by researching and inquiring into historic grievances? If, on the other hand, the enormously demanding process of research and inquiry is failing to significantly lift Maori from the economic and social difficulties they currently face, what possible justification can there be for persisting with it? It might make more sense to invest resources directly in the key areas of employment, education and health.

Finally, the fisheries battle illustrates the pitfalls of natural resource management through property rights. It is no accident that those natural resources which have been privatised by statute (fisheries, the radio spectrum) have attracted the greatest amount of litigation from 
Maori groups. If a resource is unowned, or is nationalised, there is at least some hope of securing interests in it; but it is quite otherwise once privatised. A reform driven essentially by concepts of economic efficiency ran into difficulties as a result of legal uncertainties as to whether the Crown was able to allocate the resource in the first place. There are likely to be similar consequences should there be any further privatisation of other resources such as water. 